\title{
PENGARUH PERLAKUAN SORTASI, NATRIUM HIPOKLORIT DAN FUNGISIDA PADA KACANG TANAH UNTUK MENGELIMINASI KONTAMINASI ASPERGILLUS FLAVUS
}

\author{
Sholeh Avivi ${ }^{1}$
}

\begin{abstract}
The Effect of Sorting, Sodium hypochloride (NaClO), and Fungicide Treatment on Peanut in Elimination the Aspergillus flavus Contamination. The humid tropical condition of Indonesia, the post harvest treatment, and the storage practices favour rapid growth and wide spread Aspergillus infestation on peanut. The objectives of this research was to find the best technique in controlling the Aspergillus infection on peanut. To achieve those objectives, complete randomised design in factorial with three factors was applied. The factors were grading and colour sorting (A1 = grading and colour sorting; $\mathrm{A} 2$ = without grading and colour sorting), $\mathrm{NaClO}$ blanching $(\mathrm{B} 1=$ without blanching; $\mathrm{B} 2=1.25 \% \mathrm{NaClO}$ blanching; B3=2.5\% NaClO blanching), and Benlate T-20 WP treatment (C1 = 2,5 g/L; C2 = 3 g/L; C3 = 3,5 g/L). The result showed that the best combination treatment was A2B2C3 with the minimum amount of spore on peanut seed. With those combination treatment we concluded that the grading and colour sorting, the $1.25 \% \mathrm{NaClO}$ blanching, and the application of 3,5 g/L Benlate T-20 WP could reduced the Aspergillus contamination up to $80 \%$ compare with A1B1C3 treatment.
\end{abstract}

Key words : Aspergillus flavus, fungicide, $\mathrm{NaClO}$, sortation

\section{PENDAHULUAN}

Hasil produksi kacang tanah di Indonesia berkisar 746.600 ton dengan total luas panen sebesar 696.600 ha. Hasil rata-rata 1,10 ton per hektar (Adisarwanto,2000). Produktifitas tersebut masih belum dapat mencukupi kebutuhan konsumen di Indonesia. Menurut Istiyastuti dan Yanuharso (1996) salah satu faktor penyebab rendahnya produksi kacang tanah di Indonesia adalah adanya serangan hama dan penyakit tanaman. Serangan penyebab penyakit tanaman pada kacang tanah lebih merugikan dibanding dengan serangan hama.

Pengamatan di lapang menunjukkan bahwa petani dan pedagang kacang tanah di Indonesia masih belum memperhatikan penanganan pascapanen dengan baik. Salah satu penyakit penting kacang tanah adalah penyakit cendawan penyimpanan yang disebabkan oleh Aspergillus flavus (Supartini, 1997).

Genus jamur simpan umumnya tergolong kedalam genus Aspergillus dan Penicillium yang dapat dijumpai di seluruh dunia. Jamur tersebut biasanya berada di udara dalam jumlah banyak, atau mengendap pada permukaan benda-benda yang terdapat di dalam tempat penyimpanan benih, termasuk diantaranya permukaan benih (Justice dan Bass, 1994). Sementara itu Darmadjati dan Susilo Santoso (1991) melaporkan bahwa dari 40 contoh benih kacang tanah asal daerah Jawa Barat, Jawa Tengah dan Jawa Timur, rata-rata terkontaminasi Aspergillus flavus dan Aspergillus parasiticus. pada tingkat petani masing-masing sebesar $32,4 \%$ dan $22,6 \%$

Aspergillus flavus dan Aspergillus parasiticus merupakan jamur penghasil senyawa racun yang disebut aflatoksin. Kedua jamur ini pertama kali ditemukan di Inggris tahun 1960. Toksin ini berbahaya dan mempengaruhi mekanisme kerja hati manusia, mamalia, maupun unggas sehingga menjadi faktor penyebab kanker hati (Adisarwanto, 2000). Sebanyak 58\% kejadian kanker liver dan tumor liver (hepatitis carcinoma) telah terdeteksi disebabkan oleh aflatoksin (Bryden 1999; Sudjadi et al. 1999). Disamping itu, aflatoksin pada hewan juga memicu keguguran, menurunkan bobot tubuh, menyebabkan kanker hati dan haemmorage (pembengkakan otot) (Duryatmo, 2001).

Di Indonesia, infeksi Aspergillus flavus pada pertanaman kacang tanah di lapang, benih kacang di penyimpanan, benih di pasaran dan biji konsumsi terjadi dengan tingkat serangan sekitar 60\%-80\% dengan kandungan aflatoksin 40-4100 ppm. Sedangkan kandungan aflatoksin pada kacang tanah siap saji yang beredar di supermarket dan pasar-pasar lokal mencapai 1000 ppm (Sudjadi et al. 1999). Kadar sebesar itu jauh melebihi kadar yang diperkenankan

\footnotetext{
${ }^{1}$ Dosen Jurusan Budidaya Pertanian Fakultas Pertanian Universitas Jember, Jl. Kalimantan 23, Jember 68121
} 
untuk konsumsi di Australia yaitu $\leq 15$ ppm (Hansen \& Norman, 1999).

Perkembangan jamur Aspergillus flavus dapat diminimalkan dengan memberikan perlakuanperlakuan pascapanen hingga di penyimpanan. Perlakuan tersebut meliputi cara dan intensitas pengeringan saat panen, teknik pencucian dan penggunaan fungisida sebelum benih disimpan, dan sebagainya (Wright \& Cruickshank, 1999).

Penelitian ini dilakukan untuk mengeliminasi perkembangan Aspergillus flavus dengan cara memberikan perlakuan pascapanen. Perlakuan tersebut diharapkan dapat menghasilkan kacang tanah kualitas ekspor (kadar aflatoksinnya rendah). Informasi ini akan sangat berguna untuk petani, produsen benih, pihak industri, dan bagi pihak eksportir dalam mengontrol perkembangan Aspergillus flavus pada kacang tanah selama kacang tanah disimpan atau selama kacang tanah berada di perjalanan menuju negara lain untuk di ekspor.

\section{METODE PENELITIAN}

Penelitian dilaksanakan di Laboratorium Kultur Jaringan, Laboratorium Teknologi Benih, Jurusan Agronomi, Fakultas Pertanian, Universitas Jember pada bulan November 2001 sampai Januari 2002.

Bahan yang digunakan dalam penelitian ini terdiri dari: benih kacang tanah varietas Singa, Bayclin (bahan aktif NaClO 5\%), Sunlight cair, Benlate T-20 WP (bahan aktif benomil 20\% dan tiram 20\%), media PDA (Potato Dextrose Agar), kertas merang, plastik, aquadest dan kantung plastik. Alat-alat yang yang digunakan dalam penelitian ini adalah gelas botol, cawan porselin, Erlenmeyer, gelas ukur, tabung reaksi, handsprayer, jarum ent, kapas, timbangan digital, oven, mikroskop, laminar air flow hood, lup, shaker, alat pengecambah, lemari penyimpanan, tabung reaksi, tempat mengecambahkan benih kacang tanah, inkubator, autoklaf dan Haemositometer.

Penelitian dilakukan dengan menggunakan rancangan dasar RAL faktorial dengan 3 faktor: penyortiran $\left(\mathrm{A}_{1}=\right.$ Tidak disortir; $\mathrm{A}_{2}=$ Disortir menurut bentuk warna dan ukuran normal), pencucian dengan $\mathrm{NaClO}\left(\mathrm{B}_{1}=\right.$ Tidak dicuci; $\mathrm{B}_{2}=1.25 \% \mathrm{NaClO}$ $+5-7$ tetes detergen cair selama 10 menit; $B_{3}=2.5 \%$ $\mathrm{NaClO}+5-7$ tetes detergen cair selama 10 menit), dan pencucian dengan Benlate T-20 WP $\left(\mathrm{C}_{1}=2,5\right.$ gram $/ 1$ liter air; $C_{2}=3$ gram $/ 1$ liter air; $C_{3}=3,5$ gram $/ 1$ liter air). Data yang diperoleh diuji dengan uji $F$, dilanjutkan dengan Uji Duncan taraf 0,05\% bila uji F berbeda nyata.

Perlakuan penyortiran polong kacang tanah normal dilakukan berdasarkan karakteristik umum antara lain: polong berbentuk utuh dengan guratan yang jelas, tidak tampak kusut, kulit polong berwarna coklat dan keras, sedangkan untuk benih dipilih yang sehat berwarna merah muda dengan bentuk utuh, tidak kusut dan bernas.

Perlakuan pencucian dengan NaClO dilakukan dengan cara merendam polong/benih dalam $\mathrm{NaClO}$ sesuai perlakuan ditambah detergen cair 5-7 tetes Sunlight selama 10 menit. Perlakuan dengan fungisida dilakukan dengan cara polong/benih kacang tanah direndam dalam Benlate T-20 WP selama 10 menit sesuai perlakuan kemudian dibilas dengan aquadest steril sebanyak tiga kali. Seluruh polong/benih kacang tanah yang telah diberi perlakuan dikering anginkan pada tempat yang teduh berkisar 1-2 hari, sehingga mencapai kadar air konstan 8-9 persen. Kadar air diukur dengan metode oven. Setelah dikeringkan polong/benih dimasukkan ke dalam kantung plastik, masing-masing berisi 200 gram polong/benih kacang tanah. Kemudian polong/benih disimpan pada ruangan penyimpanan yang bersuhu $20^{\circ} \mathrm{C}$ dengan kelembaban relatif berkisar $80 \%-85 \%$ selama 10 minggu setelah penyimpanan (MSP). Pada minggu ke-2, 6, dan 10 MSP masing-masing perlakuan diambil 20 polong dan 15 benih kacang tanah secara acak untuk diamati berdasarkan parameter yang diuji. Tidak dilakukan inokulasi jamur sebelum simpan dalam penelitian ini.

Untuk identifikasi jamur setelah penyimpanan, pengamatan pada 2, 6, dan 10 MSP dilakukan 3 hari setelah jamur yang berasal dari polong/benih ditumbuhkan pada media PDA (hal ini dilakukan untuk memastikan jamur yang menginfeksi adalah Aspergillus flavus, jamur/mikroba lain tidak diamati). Jamur yang tumbuh diambil dengan jarum ent untuk diidentifikasi. Untuk mengetahui bahwa jamur yang tumbuh adalah Aspergillus flavus dilakukan pengamatan secara mikroskopis.

Untuk pengamatan jumlah spora Aspergillus flavus yang menginfeksi polong atau benih, sebanyak 20 polong atau 15 benih dikocok dengan $10 \mathrm{ml}$ larutan triton 0,01\% selama 15 menit hingga larutan homogen, selanjutnya $0,5 \mathrm{ml}$ suspensi diamati dengan haemocytometer dengan teknik berikut. Larutan suspensi $0,5 \mathrm{ml}$ diteteskan pada gelas benda dari haemocytometer, kemudian dihitung jumlah spora per 
bidang pandang. Perhitungan diulang tiga kali untuk mendapatlkan rerata jumlah spora. Jadi untuk $10 \mathrm{ml}$ larutan triton atau 20 biji dan 15 polong kacang tanah jumlah suspensi dapat diketahui.

Parameter yang diamati adalah: kadar air benih kacang tanah (jika kadar air selama simpan untuk seluruh perlakuan hampir konstan dan tidak berbeda nyata maka dapat diyakini bahwa perkembangan infeksi Aspergillus flavus benar-benar disebabkan oleh perlakuan bukan oleh perbedaan kadar air), persentase daya kecambah benih (metode uji kertas digulung dalam plastik/UKDdP), persentase infeksi pada polong dan benih, dan jumlah spora pada benih dan polong.

\section{HASIL DAN PEMBAHASAN}

Kadar Air Kacang Tanah. Dari hasil analisa didapatkan bahwa kadar air benih sebelum simpan hingga pengamatan pada minggu ke-10 berbeda tidak nyata. Hasil pengukuran kadar air benih kacang tanah sebelum dan sesudah penyimpanan pada setiap perlakuan yang berbeda nampak pada Gambar 1 dan Tabel 1. Berdasarkan uji statistik, tidak ada perbedaan kadar air antar perlakuan baik sebelum maupun sesudah simpan.

Kadar air merupakan faktor primer terhadap perkembangan jamur Aspergillus sp. (Sjahdan, 1982 dalam Supartini, 1997). Dalam penyimpanan Aspergillus flavus akan tumbuh dan menghasilkan aflatoksin pada penyimpanan kacang tanah dengan kadar air yang mencukupi untuk tumbuhnya jamur (Wilson, 1995). Pada penelitian ini kadar air simpan 8-9\% mampu menumbuhkan jamur Aspergillus flavus.

Benih yang disimpan pada kantung plastik sampai dengan 10 minggu menunjukkan peningkatan kadar air dari sebelum penyimpanan antara 7-8\% dan setelah penyimpanan menjadi antara 8-9\% (Gambar 1; Tabel 2). Peningkatan kadar air benih tersebut dapat disebabkan adanya kelembaban relatif ruang penyimpanan.

Lengas selama penyimpanan sangat mempengaruhi viabilitas benih. Sifat benih yang higroskopis memungkinkan selalu mengadakan keseimbangan dengan udara sekitarnya (Syamsidi, 1984). Menurut Lita Sutopo (1985) bahwa kandungan air yang tinggi dalam benih dengan udara yang rendah dapat menyebabkan penguapan air dari dalam benih, serta mempertinggi lengas udara di sekitar benih. Sebaliknya kadar air yang rendah dengan kelembaban disekitar benih tinggi akan mengakibatkan terjadinya penyerapan air oleh benih sampai tercapainya keadaan yang seimbang.

Kenaikan kadar air benih selama masa simpan akan berubah sesuai dengan lengas dan suhu ruang penyimpanan sehingga akan mencapai kadar yang seimbang dengan udara sekitar dan akan mengalami penurunan bila penyimpanan dilanjutkan dalam waktu yang lebih lama. Hal ini sesuai dengan penelitian Syamsidi (1984), yang menyatakan bahwa peyimpanan benih kacang tanah dan benih kedelai sampai masa penyimpanan 3 bulan, kadar air benih

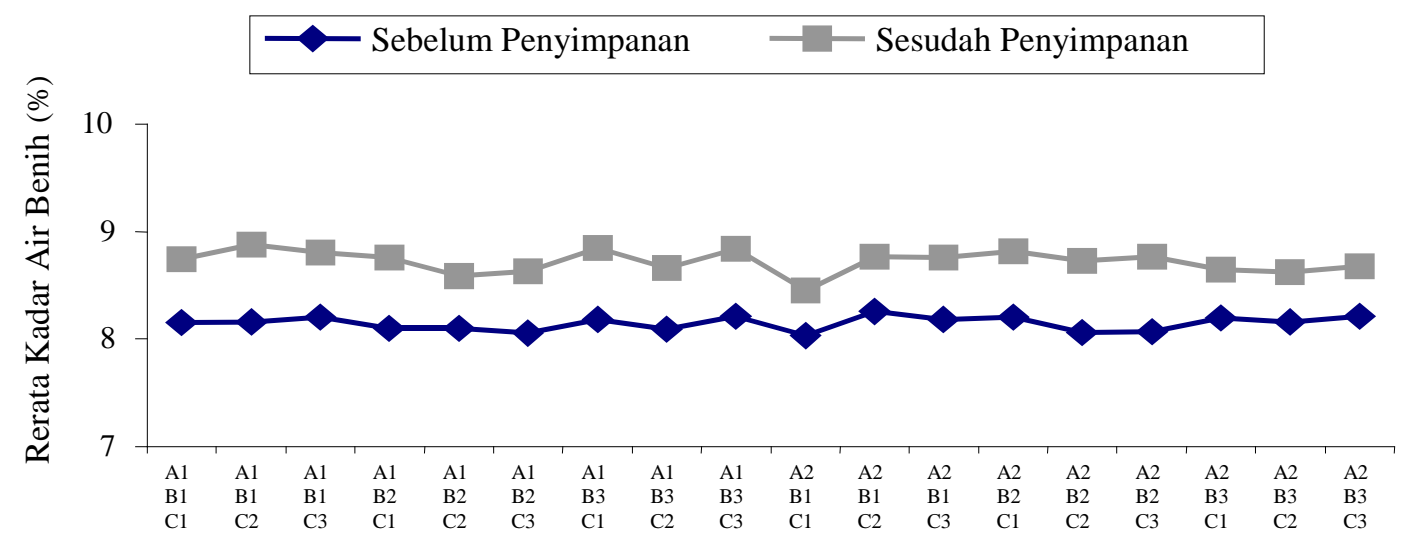

Kombinasi Perlakuan

Gambar 1. Rata - rata kadar air benih sebelum dan sesudah simpan 
akan mengalami kenaikan, sedangkan penyimpanan benih sampai 9 bulan akan mengalami penurunan

Tabel 1. Rata-rata Jumlah Spora pada Benih Akibat Interaksi Antara Penyortiran, Pencucian dengan $\mathrm{NaClO}$ dan Benlate T-20 WP Minggu ke-6 MSP

\begin{tabular}{ccc}
\hline Kode Perlakuan & $\begin{array}{c}\text { Rata-rata } \\
\text { Jumlah Spora }\end{array}$ & Notasi \\
\hline A1 B1 C3 & 15.1833 & $\mathrm{a}$ \\
A1 B1 C1 & 14.9733 & $\mathrm{a}$ \\
A1 B3 C1 & 14.4433 & $\mathrm{ab}$ \\
A1 B2 C1 & 14.3100 & $\mathrm{abc}$ \\
A1 B1 C2 & 14.2833 & $\mathrm{abc}$ \\
A1 B3 C2 & 12.9867 & $\mathrm{bcd}$ \\
A1 B2 C3 & 12.7533 & $\mathrm{~cd}$ \\
A1 B2 C2 & 12.5800 & $\mathrm{~d}$ \\
A1 B3 C3 & 12.4033 & $\mathrm{~d}$ \\
A2 B1 C2 & 10.6233 & $\mathrm{e}$ \\
A2 B1 C1 & 9.9700 & $\mathrm{ef}$ \\
A2 B1 C3 & 9.0467 & $\mathrm{f}$ \\
A2 B2 C1 & 6.6800 & $\mathrm{~g}$ \\
A2 B3 C2 & 5.1400 & $\mathrm{~h}$ \\
A2 B3 C3 & 4.9500 & $\mathrm{~h}$ \\
A2 B3 C1 & 4.9100 & $\mathrm{~h}$ \\
A2 B2 C2 & 4.8500 & $\mathrm{~h}$ \\
A2 B2 C3 & 3.0367 & $\mathrm{i}$ \\
\hline
\end{tabular}

Keterangan : angka-angka yang diikuti huruf yang sama menunjukkan berbeda tidak nyata berdasar uji Duncan pada taraf 5\%.

kadar air benih. Karena kadar air selama penyimpanan tidak berbeda nyata antar perlakuan maka dapat diyakini bahwa perbedaan data antar perlakuan bukan disebabkan oleh perbedaan kadar air, tapi lebih disebabkan oleh perbedaan perlakuan yang diuji.

Persentase Daya Berkecambah Benih Kacang Tanah. Hasil analisis statistik terhadap pengaruh ketiga faktor terhadap daya berkecambah benih kacang tanah setelah penyimpanan mingu ke-2 sampai minggu ke-10 menunjukkan perbedaan yang tidak nyata antara perlakuan sortir dan interaksi antar ketiganya, sedangkan untuk perlakuan pencucian dengan NaClO dan Benlate T-20 WP menunjukkan perbedaan yang nyata pada minggu ke-6 dan 10 (Tabel 2), dimana perlakuan tanpa pencucian dengan $\mathrm{NaClO}$ 0\% (B1) menurunkan daya berkecambah benih. Ini dapat diartikan bahwa perlakuan pencucian dengan $\mathrm{NaClO}$ berpengaruh nyata dalam meningkatkan daya berkecambah.

Perbedaan persentase perkecambahan benih ini diduga disebabkan adanya perbedaan tingkat serangan jamur Aspergillus flavus yang menghambat metabolisme sel di dalam benih, sehingga mempengaruhi daya kecambah benih. Menurut Syamsidi (1984) beberapa penelitian melaporkan bahwa biji-biji yang terserang fungi dalam penyimpanan memang dapat mengalami penurunan daya berkecambah benih, karena pada kondisi yang menguntungkan fungi dalam simpanan dapat menginfeksi benih pada permukaan benih maupun embrio.

Daya berkecambah kacang tanah dalam kemasam plastik pada penyimpanan sampai minggu ke-10 semakin rendah. Penurunan daya berkecambah benih diduga disebabkan oleh peningkatan kadar air benih yang merangsang pertumbuhan fungi dalam penyimpanan menjadi lebih aktif sehingga menyebabkan infeksi pada benih.

Persentase Infeksi Aspergillus flavus. Hasil analisis statistik terhadap data persentase polong dan benih terinfeksi akibat perlakuan sortir, pencucian dengan $\mathrm{NaClO}$, dan Benlate menunjukkan perbedaan yang nyata pada minggu ke 2, 6, dan 10, kecuali pada persentase polong yang terinfeksi pada minggu ke-2. Persentase infeksi pada polong tanpa sortir (A1) berbeda nyata dengan polong disortir (A2), kecuali pada minggu ke-2, dimana polong tanpa disortir (A1) lebih tinggi terinfeksi dari pada polong disortir (A2).

Demikian juga dengan persentase infeksi Aspergillus flavus terhadap perlakuan penyortiran biji dimana biji tanpa sortir (A1) lebih tinggi tingkat infeksinya bila dibandingkan dengan biji yang disortir (A2). Ini disebabkan benih tanpa sortiran bercampur dengan benih rusak atau tidak sehat, benih tanaman lain dan kotoran, dengan demikian patogen terbawa bersama sebelum simpan, sehingga terjadi peningkatan infeksi patogen, nampak pada Gambar 2a dan $2 b$.

Rata-rata persentase infeksi pada polong yang mengalami perlakuan tanpa pencucian dengan $\mathrm{NaClO}$ 0\% (B1) pada minggu ke-10 menunjukkan perbedaan yang nyata dengan polong yang mengalami pencucian dengan $\mathrm{NaClO}$. Persentase infeksi terendah dijumpai pada perlakuan pencucian dengan $\mathrm{NaClO}$ 1,25\% (B2) 


\begin{tabular}{|c|c|c|c|c|c|c|c|c|c|c|c|c|c|c|c|c|c|}
\hline \multirow{3}{*}{ Perlakuan } & \multicolumn{6}{|c|}{ Rata-rata Minggu ke-2 } & \multicolumn{5}{|c|}{ Rata-rata Minggu ke-6 } & \multicolumn{6}{|c|}{ Rata-rata Minggu ke-10 } \\
\hline & \multicolumn{6}{|c|}{ Parameter } & \multicolumn{5}{|c|}{ Parameter } & \multicolumn{6}{|c|}{ Parameter } \\
\hline & 1 & 2 & 3 & 4 & 5 & 6 & 2 & 3 & 4 & 5 & 6 & 1 & 2 & 3 & 4 & 5 & 6 \\
\hline A1 & $8.1 \mathrm{a}$ & 100a & $4.4 \mathrm{a}$ & $4.1 \mathrm{a}$ & $0.4 \mathrm{a}$ & $0.4 \mathrm{a}$ & $87.4 \mathrm{a}$ & $30.4 a$ & $19.6 \mathrm{a}$ & $*$ & $16.6 \mathrm{a}$ & $8.7 \mathrm{a}$ & $71.4 \mathrm{a}$ & $45.2 \mathrm{a}$ & $45.2 \mathrm{a}$ & $*$ & $28.8 \mathrm{a}$ \\
\hline A2 & $8.2 \mathrm{a}$ & $100 \mathrm{a}$ & $2.2 b$ & $2.6 a$ & $0.2 \mathrm{~b}$ & $0.2 b$ & $90.0 \mathrm{a}$ & $21.7 b$ & $11.1 b$ & $*$ & $7.5 b$ & $8.7 \mathrm{a}$ & $74.6 \mathrm{a}$ & $40.4 \mathrm{~b}$ & $31.9 b$ & * & $18.9 \mathrm{~b}$ \\
\hline B1 & $8.2 \mathrm{a}$ & $100 \mathrm{a}$ & $1.9 \mathrm{a}$ & $1.1 \mathrm{a}$ & $0.4 \mathrm{a}$ & $0.4 \mathrm{a}$ & $86.5 b$ & $27.4 \mathrm{a}$ & 18.3a & $*$ & $14.6 \mathrm{a}$ & $8.7 \mathrm{a}$ & $70.4 b$ & $45.4 a$ & $42.2 \mathrm{a}$ & * & $28.6 \mathrm{a}$ \\
\hline B2 & $8.1 \mathrm{a}$ & 100a & $4.1 \mathrm{a}$ & $4.4 \mathrm{a}$ & $0.3 a$ & $0.3 a$ & $92.0 \mathrm{a}$ & $23.7 \mathrm{a}$ & 13.3a & $*$ & $10.9 b$ & $8.7 \mathrm{a}$ & 76.3a & $41.6 a$ & $33.3 b$ & $*$ & $19.6 \mathrm{c}$ \\
\hline B3 & $8.2 \mathrm{a}$ & $100 \mathrm{a}$ & 4.a & $4.5 \mathrm{a}$ & $0.2 \mathrm{a}$ & $0.2 \mathrm{a}$ & 87.6ab & $27.0 \mathrm{a}$ & $14.4 \mathrm{a}$ & $*$ & $10.8 b$ & $8.7 \mathrm{a}$ & 72.2ab & $41.4 \mathrm{a}$ & $40.0 \mathrm{a}$ & $*$ & $23.4 \mathrm{~b}$ \\
\hline C1 & $8.2 \mathrm{a}$ & $100 \mathrm{a}$ & 3.3a & $4.4 \mathrm{a}$ & $0.3 a$ & $0.3 a$ & 84.6b & $27.8 b$ & $19.4 \mathrm{a}$ & $*$ & $12.4 \mathrm{a}$ & $8.7 \mathrm{a}$ & $69.6 \mathrm{~b}$ & $44.7 \mathrm{a}$ & $40.0 \mathrm{a}$ & $*$ & $25.5 \mathrm{a}$ \\
\hline C2 & 8.1a & $100 \mathrm{a}$ & 3.3a & $2.8 \mathrm{a}$ & $0.4 \mathrm{a}$ & $0.4 \mathrm{a}$ & 88.5ab & 26.7ab & $15.0 \mathrm{ab}$ & $*$ & $12.6 \mathrm{a}$ & $8.7 \mathrm{a}$ & 73.7ab & $44.2 \mathrm{a}$ & $41.1 \mathrm{a}$ & $*$ & 23.3a \\
\hline C3 & $8.2 \mathrm{a}$ & 100a & 3.3a & $2.9 \mathrm{a}$ & $0.1 \mathrm{a}$ & $0.1 \mathrm{a}$ & $93.0 \mathrm{a}$ & $23.7 \mathrm{a}$ & $11.7 \mathrm{~b}$ & $*$ & $11.1 \mathrm{~b}$ & $8.7 \mathrm{a}$ & $75.6 \mathrm{a}$ & 39.6a & $34.4 \mathrm{a}$ & $*$ & $22.7 \mathrm{a}$ \\
\hline
\end{tabular}

Keterangan: Huruf yang sama pada kolom menunjukkan berbeda tidak nyata pada uji Duncan taraf 5\%; 1. Kadar Air Benih (\%); 2. Daya Tumbuh Benih (\%); 3. Jumlah Benih Terinfeksi Aspergillus flavus; 4. Jumlah Polong Terinfeksi Aspergillus flavus; 5. Jumlah Spora pada Benih; 6. Jumlah Spora pada Polong; * = data tidak disajikan sebab terjadi interaksi (Tabel 1). 


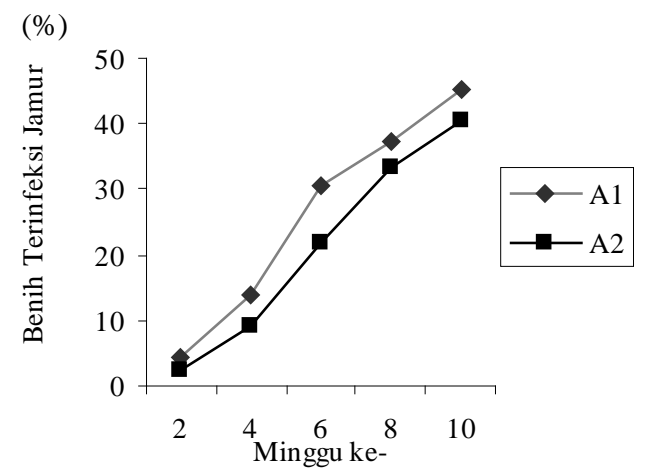

Gambar 2a. Benih terinfeksi A. flavus akibat pengaruh penyortiran

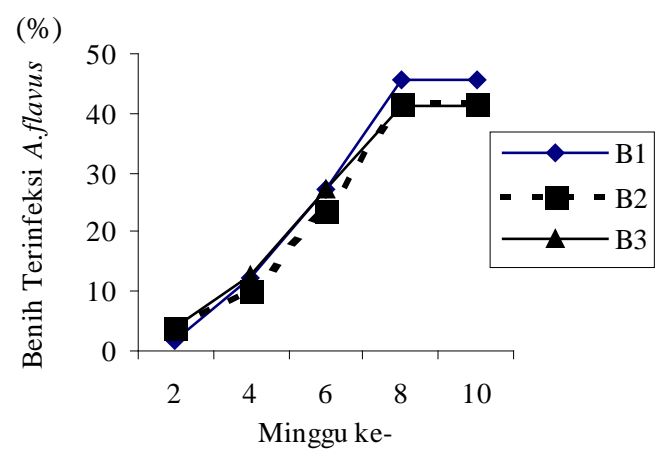

Gambar 2c. Benih terinfeksi A. flavus akibat pengaruh pencucian dengan $\mathrm{NaClO}$

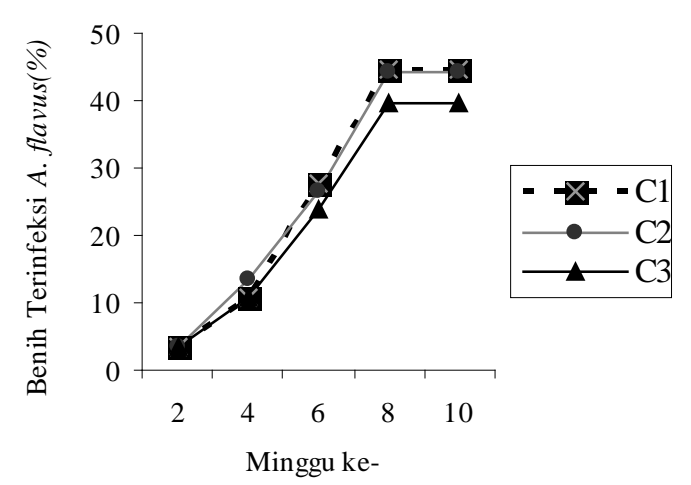

Gambar 2e. Benih terinfeksi A. flavus akibat pengaruh pencucian dengan Benlate T-20 WP



Gambar 2b. Polong terinfeksi A. Flavus akibat pengaruh penyortiran

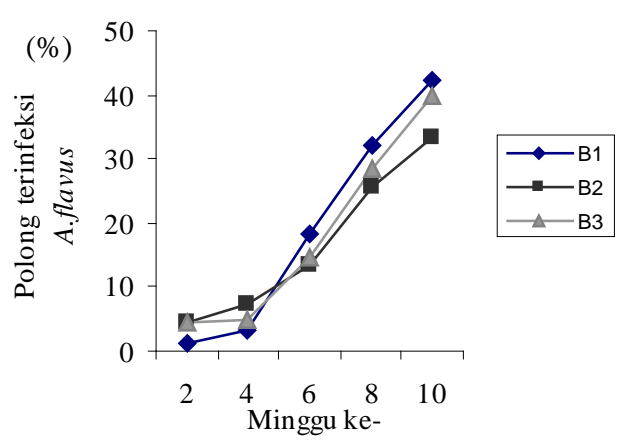

Gambar 2d. Polong terinfeksi A. flavus akibat pengaruh pencucian dengan $\mathrm{NaClO}$

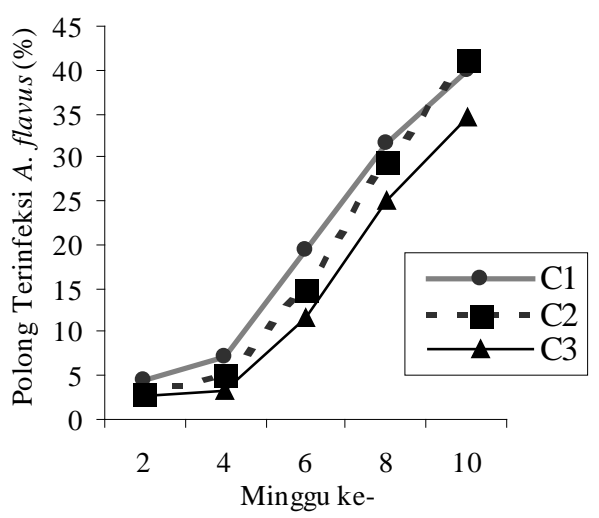

Gambar 2f. Polong terinfeksi A. flavus akibat pengaruh pencucian dengan Benlate T-20 WP 
dibandingkan dengan polong tanpa pencucian dengan NaClO. Sedangkan perlakuan B3 untuk menekan Aspergillus flavus lebih tinggi dibandingkan B2, sebab semakin tinggi konsentrasi $\mathrm{NaClO}$ diduga dapat menimbulkan kerusakan pada sel kacang tanah, seperti hasil dari pengaruh B3 pada daya tumbuh benih menurunkan kemampuan benih untuk berkecambah. Menurut Achmad (1992), NaClO yang terkandung pada Bayclin merupakan bahan pemutih yang kekuatan oksidasinya besar dan biasa digunakan sebagai zat disinfektan dan zat penghilang bau.

Pengaruh perlakuan Benlate T-20 WP berbeda nyata pada minggu ke-6, sedangkan minggu ke-2 dan ke-10 tidak berbeda nyata, sebab yang pasti dari fakta ini belum diketahui.

Lama penyimpanan mempengaruhi peningkatan jumlah polong dan benih yang terinfeksi Aspergillus flavus (Gambar 2a-2f). Peningkatan persentase infeksi Aspergillus flavus pada polong dan benih tersebut kemungkinan besar dipengarui oleh kondisi lingkungan simpan. Karena polong dan benih disimpan dalam kantung plastik, maka kandungan air dan suhu kemasan dapat menjadi lebih tinggi, ditambah dengan pertukaran udara yang sangat kurang. Kondisi tersebut sangat baik untuk perkembangan jamur.

Jumlah Spora. Hasil analisis statistiuk terhadap data jumlah spora pada polong kacang tanah setelah penyimpanan dengan berbagai perlakuan disajikan pada Tabel 2.

Jumlah spora Aspergillus flavus pada polong kacang tanah akibat perlakuan penyortiran menunjukkan perbedaan yang nyata. Polong kacang tanah yang disortir (A2) jumlah sporanya lebih sedikit hingga 52.1\% dibandingkan dengan polong yang tidak disortir (A1). Ini disebabkan polong tanpa sortir bercampur dengan polong kacang tanah rusak, benih tanaman lain dan kotoran, sehingga persentase jumlah spora lebih tinggi.

Sedangkan jumlah spora pada polong paling banyak yaitu perlakuan tanpa pencucian dengan NaClO (B1) hingga 45.7\% dari pada jumlah spora terendah (B2). Peningkatan jumlah spora terdapat pada kacang tanah tanpa perlakuan pencucian dengan $\mathrm{NaClO}$. Ini disebabkan pengaruh dari pencucian $\mathrm{NaClO}$ dapat menghambat pertumbuhan spora jamur Aspergillus flavus.

Menurut Hansen \& Norman (1999) penyortiran dan pencucian polong dan biji kacang tanah di penyimpanan merupakan cara utama yang dilakukan oleh industri di Australia untuk mengurangi kadar aflatoksin yang dihasilkan oleh jamur simpan yaitu Aspergillus flavus.

Interaksi antara perlakuan penyortiran, pencucian dengan Bayclin dan Benlate T-20 WP berbeda sangat nyata terhadap parameter jumlah spora pada benih minggu ke-6, disajikan pada Tabel 1. Dari Tabel 1 tersebut nampak bahwa perlakuan kombinasi terbaik terjadi dari interaksi perlakuan A2B2C3. Dengan kombinasi perlakuan tersebut jumlah spora yang menyerang benih berkurang hingga $19.7 \%$ bila dibandingkan dengan kombinasi perlakuan A1B1C3. Hal yang sama terjadi pada pengamatan minggu ke-10 bahwa kombinasi perlakuan terbaik diperoleh dari perlakuan A2B2C3 (Tabel 2).

\section{SIMPULAN}

Berdasarkan hasil penelitian di atas dapat disimpulkan sebagai berikut:

1. Penyortiran dapat mengurangi perkembangan Aspergillus flavus selama penyimpanan.

2. Pada pengamatan Minggu ke 10, pencucian dengan $\mathrm{NaClO}$ 1,25\% (B2) lebih efektif menekan perkembangan jamur Aspergillus flavus dibanding dengan perlakuan tanpa pencucian dengan $\mathrm{NaClO}$ (B1).

3. Pemberian Benlate T-20 WP 3,5 g/L lebih efektif menekan perkembangan Aspergillus flavus dibanding dengan pemberian Benlate T-20 WP dosis $2,5 \mathrm{~g} / \mathrm{L}$.

\section{SANWACANA}

Terimakasih disampaikan kepada Proyek DUE Universitas Jember (IBRD Loan No. 4043-IND), Direktorat Jenderal Pendidikan Tinggi, Departemen Pendidikan Nasional atas bantuan dana penelitian. Kepada Yenny Silvia atas bantuannya dalam melaksanakan penelitian. Kepada Dra. Erna Rochiyati, MS. juga diucapkan terimakasih atas perannya sebagai penyelaras bahasa.

\section{DAFTAR PUSTAKA}

Acmad, H. 1992. Kimia Unsur dan Radiokimia. PT. Citra Aditya Bakti. Bandung. 
Adisarwanto, T. 2000. Meningkatkan Produksi Kacang Tanah di Lahan Sawah \& Lahan Kering. Penebar Swadaya. Jakarta.

Bryden, WL. 1999. Aflatoxin and reduction in contaminated commodities. In RG. Dietzgen (ed.). Aciar Proceeding : Elimination of Aflatoxin Contamination in Peanut.

Darmadjati dan S. Susila. 1991. Penanganan Pascapanen Kacang Tanah. Makalah Pertemuan Aplikasi Paket Teknologi PertanianI, Denpasar 8-12 September 1991.

Duryatmo, S. 2001. Racun Mematikan Itu Bernama Aflatoxin. Trubus 374. Januari 2001/XXXII.

Hansen, RB. and KL. Norman. 1999. Economic Importance of aflatoxin to the Australian peanut industry. In RG. Dietzgen (ed.). Aciar Proceeding : Elimination of Aflatoxin Contamination in Peanut.

Istiyastuti dan T. Yanuharso. 1996. Budidaya Aneka Tanaman Pangan. Trigeda Karya. Bandung.

Justice, DL. dan LH. Bass. 1994. Prinsip dan Praktek Penyimpanan Benih, Terjemahan. Rajawali Pers. Jakarta.
Sudjadi, S., M. Mahmud, DS. Darmadjati, A. Hidayat, S. Widowati, and A. Widiati. 1999. Aflatoxin research in Indonesia. In RG. Dietzgen (ed.). Aciar Proceeding : Elimination of Aflatoxin Contamination in Peanut.

Supartini, V. 1997. Dampak Serangan Jamur Aspergillus flavus terhadap Kandungan Aflatoksin pada Kacang Tanah dalam Beberapa Jenis Kemasan. Laporan Penelitian. Lemlit UNEJ, Jember. Tidak dipublikasikan.

Sutopo, L. 1985. Tekhnologi Benih. CV. Rajawali. Jakarta.

Syamsidi, SR. 1984. Penyakit dalam Simpanan (Penyakit gudang). Faperta Unibraw. Malang.

Wilson, DM. 1995. Management of Mycotoxin in peanut in. HA., Moelouk and FM. Shokes: Peanut Health Management. APS Prss. Minnesota.

Wright, GC. And AL. Cruickshank. 1999. Agronomic, genetic, and crop modelling strategies to minimise aflatoxin contamination in peanut. In RG. Dietzgen (ed.). Aciar Proceeding : Elimination of Aflatoxin Contamination in Peanut. 